\title{
Dispersal and coexistence of two non-native crayfish species (Pacifastacus leniusculus and Procambarus clarkii) in NE Portugal over a 10-year period
}

\author{
J.M. Bernardo(1), A.M. Costa(1), S. Bruxelas ${ }^{(2)}$, A. Teixeira ${ }^{(3)}$ \\ Received February 7, 2011 \\ Revised May 1, 2011 \\ Accepted May 18, 2011
}

Key-words:

Pacifastacus

leniusculus,

Procambarus

clarkii,

dispersal

rate,

crayfish

coexistence

\section{ABSTRACT}

NE Portugal is one of the most isolated and low populated regions of Western Europe. Recently, two American crayfish species reached this area: signal crayfish Pacifastacus leniusculus coming from Spain and red swamp crayfish Procambarus clarkii in its northward expansion. The dispersion of both species was followed throughout the last decade in river Maçãs (Douro catchment). Our results support the hypothesis of faster downstream colonisation. The mean spread rate of signal crayfish was faster for the downstream expansion, $2.8 \mathrm{~km} \cdot \mathrm{yr}^{-1}$, while the upstream rate was $1.7 \mathrm{~km} \cdot \mathrm{yr}^{-1}$. Exceptionally, in one period, the rate of spread reached $6.7 \mathrm{~km} \cdot \mathrm{yr}^{-1}$, which was apparently caused by downstream washing in extreme conditions of flow. The mean rate of spread is higher than the observed in other studies which may also be related to the low current velocity of late spring and summer that provides favourable conditions for a fast upstream colonisation. Coexistence of signal and red swamp crayfish was detected in a large river sector. Signal crayfish strongly dominates in the upper and intermediate sectors which are the colder part of the river and in the lower sectors, species abundances are not significantly different. Winter temperature in the higher altitude reaches seems to moderate the competitive abilities of $P$. clarkii.

RÉSUMÉ

Dispersion et coexistence de deux écrevisses non-natives (Pacifastacus leniusculus et Procambarus clarkii) au NE du Portugal sur une période de 10 ans

Mots-clés :

Pacifastacus

leniusculus,

Procambarus

clarkii,
Le Nord Est du Portugal est une des régions les plus isolées et les moins peuplées de l'Europe de l'Ouest. Récemment, deux écrevisses américaines ont été introduites : l'écrevisse signal Pacifastacus leniusculus venant d'Espagne et l'écrevisse rouge de Louisiane Procambarus clarkii en expansion au Nord. La colonisation par ces deux espèces a été suivie au cours des dix dernières années dans la rivière de Maçãs (bassin du Douro). Nos résultats supportent l'hypothèse d'une colonisation plus rapide en aval. Le niveau moyen de colonisation par l'écrevisse signal a été

(1) Departamento de Paisagem, Ambiente e Ordenamento, Universidade de Évora, Rua Romão Ramalho 59, 7000-671 Évora, Portugal, jmb@uevora.pt

(2) Autoridade Florestal Nacional, Av. João Crisóstomo 26-28, 1069-040 Lisboa, Portugal

(3) CIMO - Centro de Investigação de Montanha, ESA, Instituto Politécnico de Bragança, 5301-855 Bragança, Portugal 
taux de dispersion, coexistence d'écrevisses plus rapide en aval, soit 2,8 km par an, comparé à 1,7 km par an en amont. Exceptionnellement, sur une période, le niveau de colonisation a atteint 6,7 km par an car les écrevisses on été apparemment emportées en aval à cause des conditions extrêmes d'écoulement. La propagation moyenne est plus élevée que ce qui est observé dans d'autres études, ce qui peut être mis en relation avec la faible vitesse du courant en fin de printemps et en été, favorisant une colonisation rapide en amont. La coexistence de l'écrevisse signal et de l'écrevisse rouge a été observée dans une grande partie de la rivière. L'écrevisse signal domine dans la partie haute et plus froide de la rivière, alors que dans le secteur le plus bas il n'y a pas de différence significative entre les deux espèces. La température hivernale, observée en plus haute altitude, semble modérer les capacités de compétition de P. clarkii.

\section{INTRODUCTION}

The accidental or deliberate introduction and translocation of invasive non-native species are important drivers of biodiversity loss (Millennium Ecosystem Assessment, 2005). In many regions of the world these species are the first or second most important threat to freshwater biodiversity and ecosystem function (Lodge et al., 2000a).

Crayfish are among the most commonly introduced freshwater organisms and the invasive crayfish species are a major threat to stream ecosystems. They frequently attain a high biomass and because of their broad trophic regime (Holdich, 2002) and aggressive behaviour, crayfish affect a wide range of species. Through grazing or predation and competition crayfish affect a large part of the community and through burrowing, bioturbation (Momot, 1995; Nystrom, 2002), organic matter processing and nutrient cycling (Bernardo and Ilhéu, 1994) they may significantly impact the ecosystems.

The fast invasions by several crayfish species support the hypothesis that generalist species are well-equipped to be successful invaders (e.g. Jeschke and Strayer, 2006). In fact many crayfish species have gained a reputation as very effective invaders when introduced in new habitats with negative impact on the native crayfish species. The introduction of non-indigenous crayfish has often caused the local extinction of native crayfish species (Henttonen and Huner, 1999; Holdich et al., 1999; Lodge et al., 2000a, 2000b; Taylor, 2002; Diéguez-Uribeondo, 2006). In Europe, the generalized decline of the native crayfish populations led to the introduction and translocation of non-European species in order to replace the lost or vanishing populations.

Of the non-native crayfish that have been introduced into Europe, the most widespread species is the signal crayfish Pacifastacus leniusculus (Dana) (Souty-Grosset et al., 2006), particularly in the North, while the red swamp crayfish Procambarus clarkii (Girard) dominates in the warmer waters of Southern Europe. With different preferences on environmental conditions, they both present high dispersal abilities, fast growing populations, and wide niches, which make them very successful invaders. $P$. clarkii and $P$. leniusculus are two of the three most globally invasive crayfish species (Hobbs et al., 1989) and $P$. clarkii is listed among the "100 of the worst" invasive species in Europe (DAISIE, 2010).

NE Portugal is one of the most isolated and low populated $\left(27\right.$ inhab $\left.\cdot \mathrm{km}^{-2}\right)$ parts of Western Europe. Most rivers in this region present low levels of human impact and some are actually pristine. Recently, two American crayfish species reached the area: signal crayfish coming from Spain and red swamp crayfish in its northward expansion. Signal crayfish Pacifastacus leniusculus, after being introduced in other regions of Spain, was introduced by the Spanish authorities in 1994 in two small rivers, River San Mamed $\left(41^{\circ} 41^{\prime} \mathrm{N}, 6^{\circ} 28^{\prime} \mathrm{W}\right)$ and its tributary Arriba Stream (41 $42^{\prime} \mathrm{N}, 6^{\circ} 31^{\prime} \mathrm{W}$ ) (J.M.Jimenez - Junta de Castilla y Leon, consejeria de Medio Ambiente y Ordenacion del Territorio, pers. comm.). River San Mamed flows into the international sector of river Maçãs. Signal crayfish was detected in 1997 in river Maçãs, in Quintanilha - site 6 (Figure 1). This was the first occurrence of the signal crayfish in Portuguese waters (Bernardo et al., 2001). 


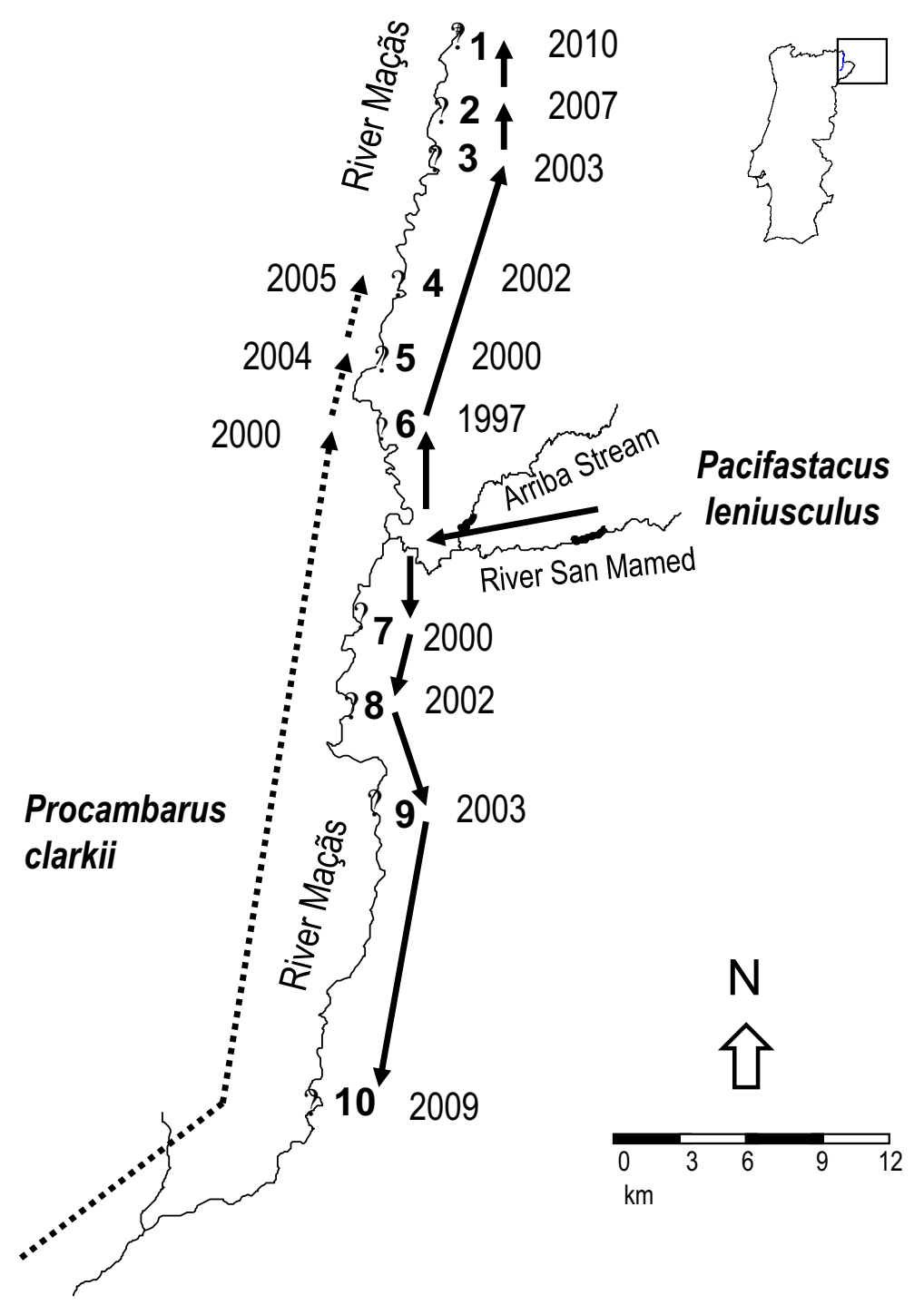

\section{Figure 1}

Location of sites in River Maçãs and distribution expansion of Pacifastacus leniusculus and Procambarus clarkii (doted lines). Black marks in Arriba Stream and River San Mamed indicate P. leniusculus introduction sites.

\section{Figure 1}

Localisation des sites sur la rivière Maçãs et chronologie de la propagation de Pacifastacus leniusculus et Procambarus clarkii (ligne pointillée). Les secteurs en gras sur la rivière Arriba et la rivière San Mamed indiquent les sites d'introduction de $P$. leniusculus.

P. clarkii was first detected in the lower reaches of river Maçãs in the 1990's. It was intentionally introduced in 1973 for farming in the province of Badajoz (SW Spain) (Gutiérrez-Yurrita et al., 1999) and, as expected, its acclimatization was very successful. The species rapidly expanded into the Portuguese inland waters and since then, through natural expansion and massive translocations, $P$. clarkii distribution expanded to the North and the species is now very widespread. With the exception of isolated areas, particularly in mountain regions, red swamp crayfish is now present in most river systems in continental Portugal.

The isolation and the natural conditions of the rivers of NE Portugal make them particularly valuable for the study of crayfish spreading and colonization. Furthermore, the co-existence of two potentially invasive crayfish species with different environmental preferences is of wide 
Table I

Sampling sites: coordinates, altitude, distance between sites and slope.

Tableau I

Sites d'échantillonnage: coordonnées, altitude, distance entre sites et pente.

\begin{tabular}{|l|c|c|c|c|c|}
\hline Site & $\begin{array}{c}\text { Latitude } \\
(\mathrm{N})\end{array}$ & $\begin{array}{c}\text { Longitude } \\
(\mathrm{W})\end{array}$ & $\begin{array}{c}\text { Altitude } \\
(\mathrm{m})\end{array}$ & $\begin{array}{c}\text { Distance } \\
(\mathrm{km})\end{array}$ & $\begin{array}{c}\text { Slope } \\
(\%)\end{array}$ \\
\hline 1. Petisqueira & $41^{\circ} 51^{\prime} 28.60^{\prime \prime}$ & $6^{\circ} 30^{\prime} 93.60^{\prime \prime}$ & 641 & & \\
\hline & & & & 3.9 & 0.56 \\
\hline 2. Deilão & $41^{\circ} 50^{\prime} 33.42^{\prime \prime}$ & $6^{\circ} 31^{\prime} 36.45^{\prime \prime}$ & 619 & & \\
\hline & & & & 3.2 & 0.66 \\
\hline 3. S. Julião Palácios & $41^{\circ} 49^{\prime} 18.29^{\prime \prime}$ & $6^{\circ} 31^{\prime} 41.00^{\prime \prime}$ & 598 & & \\
\hline & & & & 7.2 & 0.36 \\
\hline 4. Réfega & $41^{\circ} 46^{\prime} 59.61^{\prime \prime}$ & $6^{\circ} 32^{\prime} 43.19^{\prime \prime}$ & 572 & & \\
\hline & & & & 3.1 & 0.97 \\
\hline 5. Colada & $41^{\circ} 45^{\prime} 13.28^{\prime \prime}$ & $6^{\circ} 33^{\prime} 27.04^{\prime \prime}$ & 542 & & \\
\hline & & & & 4.5 & 0.20 \\
\hline 6. Quintanilha & $41^{\circ} 44^{\prime} 09.28^{\prime \prime}$ & $6^{\circ} 33^{\prime} 25.02^{\prime \prime}$ & 533 & & \\
\hline & & & & 11.2 & 0.26 \\
\hline 7. Outeiro & $41^{\circ} 40^{\prime} 36.00^{\prime \prime}$ & $6^{\circ} 36^{\prime} 06.00^{\prime \prime}$ & 504 & & \\
\hline & & & & 5.1 & 0.08 \\
\hline 8. Argozelo & $41^{\circ} 38^{\prime} 26.65^{\prime \prime}$ & $6^{\circ} 33^{\prime} 43.00^{\prime \prime}$ & 500 & & \\
\hline & & & & 6.7 & 1.03 \\
\hline 9. Ponte Vimioso & $41^{\circ} 36^{\prime} 21.05^{\prime \prime}$ & $6^{\circ} 33^{\prime} 40.89^{\prime \prime}$ & 431 & & \\
\hline & & & & 13.1 & 0.62 \\
\hline 10. Campo de Víboras & $41^{\circ} 30^{\prime} 29.49^{\prime \prime}$ & $6^{\circ} 35^{\prime} 19.59^{\prime \prime}$ & 350 & & \\
\hline
\end{tabular}

scientific interest. In this paper we present the progression of $P$. leniusculus and $P$. clarkii in the river Maçãs over a $10 \mathrm{yr}$ period.

\section{MATERIALS AND METHODS}

Maçãs is a 3rd order upland river, tributary of river Sabor (Douro basin, Trás-os-Montes, NE Portugal), flowing from North to South. Schist dominates the basin geology, with small areas of granites and calcareous rocks. The river banks are covered with dense riparian vegetation, dominated by alder (Alnus glutinosa) with also willow (Salix spp.), poplar (Populus nigra) and ash (Fraxinus angustifolia). It presents persistent flow regime, and only in very dry years (particularly with very low precipitation during late winter and spring) the stream flow stops during summer and part of the river bed dries up. In this mountainous and scarcely populated basin, the impact of human activities is reduced, there is no relevant industry and agriculture is extensive with low use of chemical fertilizers, which contributes to the good water quality. The mean annual precipitation of this region is $759 \mathrm{~mm}$ and the mean annual temperature is $12.1^{\circ} \mathrm{C}$ (meteorological station of Bragança, Instituto de Meteorologia, I.P. Portugal www.meteo.pt). Summers are hot, with mean maximum temperatures in July and August higher than $38^{\circ} \mathrm{C}$ and winters are cold, with mean minimum temperature in January of $0.5^{\circ} \mathrm{C}$. In the upper part of the catchment, the altitude is higher than $800 \mathrm{~m}$ and temperatures are lower than in the lower part (Digital Climatic Atlas of the Iberian Peninsula, Ninyerola et al., 2005).

The river slope in the study area is $0.5 \%$ with slopes between sites ranging from $0.20 \%$ to $1.03 \%$ (Table I). The river presents a pool-riffle sequence and dominant substrate is cobble and boulders providing high shelter availability. Electric conductivity presents an upstreamdownstream gradient from $33.2 \mu \mathrm{S} \cdot \mathrm{cm}^{-1}$ to $156 \mu \mathrm{S} \cdot \mathrm{cm}^{-1}$. Water temperature ranges from $1^{\circ} \mathrm{C}$ (in the colder winters) to $26^{\circ} \mathrm{C}$. Small cyprinids dominate the fish fauna, and brown trout Salmo trutta occurs in low numbers in the headwaters. 
Sampling to study the dispersal of $P$. leniusculus and $P$. clarkii took place from 2000 to 2010 in ten sites (Figure 1, Table I). Crayfish were collected using crayfish traps similar to lobster cages with entry funnels which prevent crayfish from escaping. Twenty traps were used in each site though in four occasions one or two traps were not recovered or were vandalized and in another occasion ten traps were not recovered. Sampling was done from late Spring to Autumn when hydrological conditions were suitable for sampling and crayfish were more active. The traps, baited with rainbow trout, were distributed before dusk along the river banks at a minimum distance of $20 \mathrm{~m}$ between traps and retrieved the following morning. Total sampling time was approximately $16 \mathrm{~h}$. Abundance was measured as catch per unit effort (CPUE, number of crayfish per trap night).

Since the CPUE data did not meet the assumptions of normality and homogeneity of variances, non-parametric tests were used. The CPUE differences between sites or groups of sites were assessed with the Kruskal-Wallis test, followed by post hoc comparisons with the Dwass-Steel-Critchlow-Fligner test (DSCF). Differences between the abundance of the two crayfish species in situations of coexistence were tested with Wilcoxon matched-pairs signed-ranks test (WSR). The very low CPUE values registered in the first years of detection were excluded from the statistical treatment.

\section{RESULTS}

According to informations from the local inhabitants, signal crayfish presence in river Maçãs (site 6) was detected for the first time in 1997. This means signal crayfish took three years to travel $13.8 \mathrm{~km}$, from the nearest introduction site (Arriba Stream, Figure 1) to site 6, at a spread rate of $4.6 \mathrm{~km} \cdot \mathrm{yr}^{-1}$ (Table II). From then on, the upstream expansion gradually progressed (Table II, Figure 1). The $14.8 \mathrm{~km}$ distance to site 3 was travelled in six years at an average rate of $2.5 \mathrm{~km} \cdot \mathrm{yr}^{-1}$ and further progression to site 2 and 1 was performed at 0.8 and $1.3 \mathrm{~km} \cdot \mathrm{yr}^{-1}$, respectively. The mean spread rate for the whole upper sector of river Maçãs, $21.6 \mathrm{~km}$ long from site 6 to site 1, was $1.68 \mathrm{~km} \cdot \mathrm{yr}^{-1}$ (Table II).

Downstream, signal crayfish was first captured in site 7 in 2000. No previous information exists for this site but, as CPUE is very low (0.05, corresponding to a single specimen), it is reasonable to assume that the species reached site 7 in 2000, moving from the nearest introduction site at a rate of $1.43 \mathrm{~km} \cdot \mathrm{yr}^{-1}$. Regarding the downstream expansion, site 8 was reached in 2002 at a rate of $1.71 \mathrm{~km} \cdot \mathrm{yr}^{-1}$, site 9 in $2003\left(6.7 \mathrm{~km} \cdot \mathrm{yr}^{-1}\right)$ and site 10 in 2009 $\left(2.18 \mathrm{~km} \cdot \mathrm{yr}^{-1}\right)$. For the total downstream expansion, from site 7 to site 10 , the $24.9 \mathrm{~km}$ distance was travelled in nine years, which corresponds to a mean spread rate of $2.77 \mathrm{~km} \cdot \mathrm{yr}^{-1}$ (Table II), i.e. 1.65 times faster than the mean upstream spread rate.

The observed variability of both up and downstream spread rates are possibly related to the different features of each river sector. The relationship of $P$. leniusculus spread rates to slope of the corresponding sectors of river Maçãs (Figure 2) suggests a possible connection between these two variables

In 2000, Procambarus clarkii occurred from the mouth of river Maçãs to site 6 (Table II). In 2004, the upstream progression reached site 5 at a spread rate of $1.13 \mathrm{~km} \cdot \mathrm{yr}^{-1}$ and in the following year $P$. clarkii reached site 4 at a higher rate $\left(3.1 \mathrm{~km} \cdot \mathrm{yr}^{-1}\right)$. No further upstream progression was observed in the following five years. During this period, the CPUE in site 4 remained low, ranging from 0.13 to 0.27 . Red swamp crayfish is present in $55.9 \mathrm{~km}$ of river Maçãs with a distribution overlap of $43.7 \mathrm{~km}$ with signal crayfish, from site 4 to site 1 (Table II). To compare abundances along the river sectors, the sites of the upper river sectors, i.e. sites $4,5,6$, were grouped. The lower sector sites $(8,9,10)$ were grouped as well, and the transition is represented by site 7 . All sampling periods considered, CPUE of $P$. leniusculus is smaller in the lower sectors compared with site 7 (DSCL test, $p<0.05$ ) (Table III). For P. clarkii, the upper sectors present a very low CPUE $(0.25 \pm 0.10 \mathrm{SD})$, significantly lower than in site 7 (DSCL test, $p<0.01$ ) and in the lower sectors (DSCL test, $p<0.001$ ). For the coexistence period the signal crayfish was the dominant species, outnumbering the red swamp crayfish by more than nine to one in the upper sectors (P. leniusculus $94.7 \% \pm 3.4 \mathrm{SD}$ ) and in site 7 
Table II

Progression and rate of spread of Pacifastacus leniusculus and Procambarus clarkii. Year of detection with asterisk means the species was detected during that year but there is no information for the previous year.

\section{Tableau II}

Progression et taux de propagation de Pacifastacus leniusculus et Procambarus clarkii. L'année de détection avec astérisque signifie que l'espèce a été détectée pendant cette année mais qu'il n'y avait pas d'information pour les années précédentes.

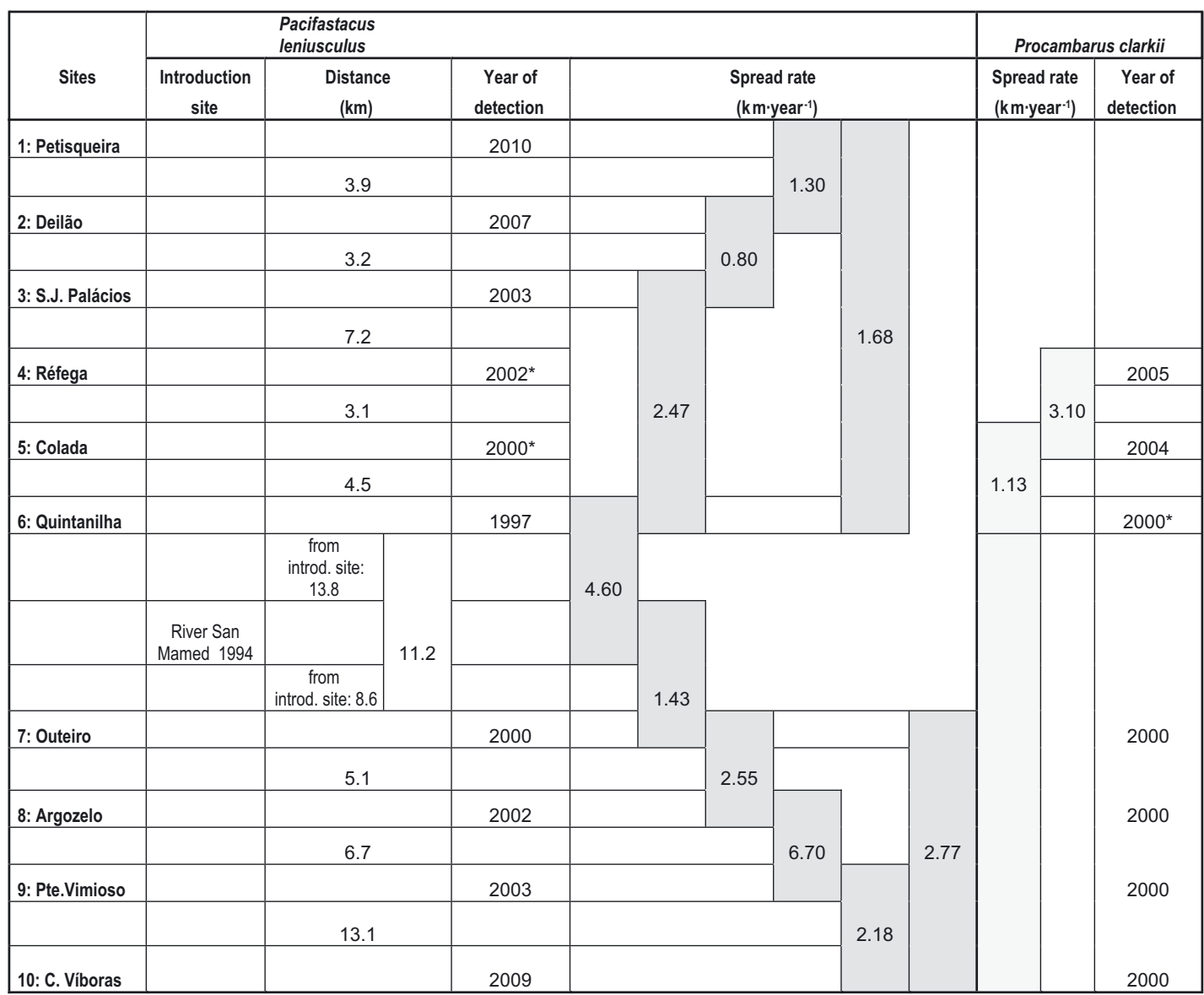

(P. leniusculus $98.8 \% \pm 9.9 \mathrm{SD}$ ). In the lower sectors $P$. leniusculus represented $63.7 \%$ (35.4 SD). The CPUE was significantly different between red swamp crayfish and signal crayfish in the upper sectors and in site 7 (WRS test, in both cases $p<0.05$ ) but not in the lower sectors

\section{DISCUSSION}

During the 10 year period of this study, it was possible to follow the successive stages of the distribution expansion of $P$. leniusculus and $P$. clarkii. The expansion was gradual and in no moment voids in the distribution were detected. If the opposite had been observed, it would mean that translocations had taken place. The colonisation rate of river Maçãs by signal crayfish in each phase ranged from 0.8 to $2.6 \mathrm{~km} \cdot \mathrm{yr}^{-1}$ with two exceptions: from the nearest introduction site, in Arriba Stream to site 6, the spread rate was $4.6 \mathrm{~km} \cdot \mathrm{yr}^{-1}$, and from site 8 to site 9, in 2002-2003, the expansion rate reached $6.7 \mathrm{~km} \cdot \mathrm{yr}^{-1}$. In the first situation, the proximity of San Mamed village to the watercourse makes possible the translocation of crayfish thus accelerating the crayfish expansion. In the second case, spates can be a possible explanation for high downstream expansion as there was a period of high flows from 


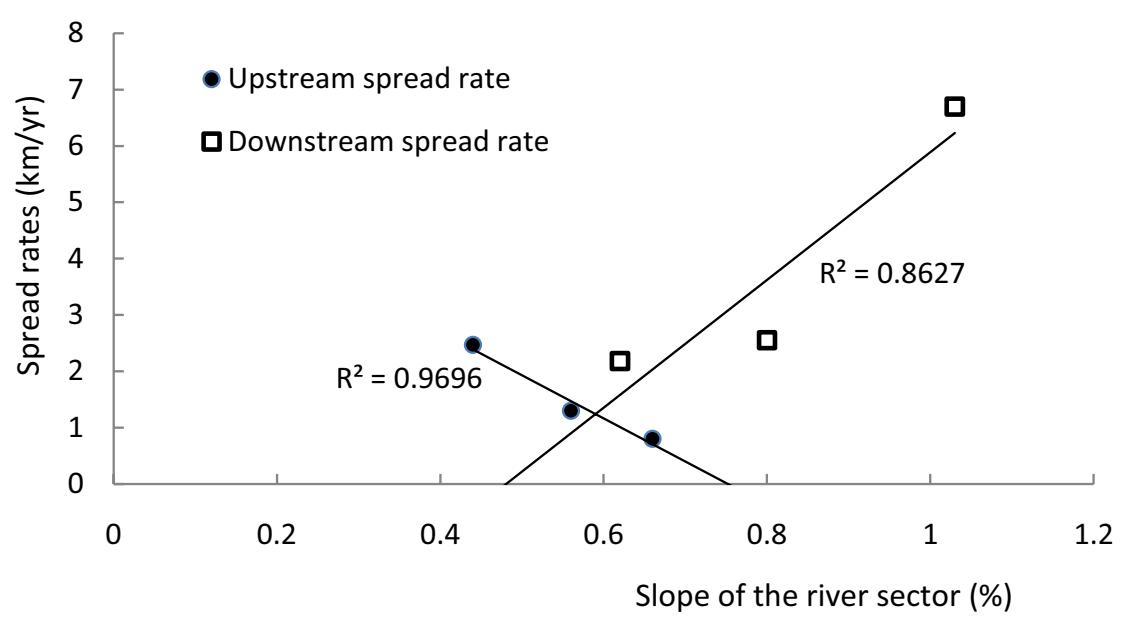

\section{Figure 2}

Upstream and downstream spread rates of Pacifastacus leniusculus and slope of river Maçãs sectors.

\section{Figure 2}

Taux d'expansion amont et aval de Pacifastacus leniusculus et pente des secteurs de la rivière Maçãs.

\section{Table III}

Mean CPUE (number of crayfish per trap night) and standard deviation (SD) of Pacifastacus leniusculus $(P I)$ and Procambarus clarkii $(P c)$ and results of Kruskal-Wallis and post hoc Dwass-Steel-CritchlowFligner tests for the comparisons of CPUE of each species among river sectors. All samples considered. Significance levels: ${ }^{*}=p<0.05,{ }^{* *}=p<0.01,{ }^{* * *}=p<0.001$, ns $=$ not significant.

\section{Tableau III}

CPUE moyennes (nombre d'écrevisses par trappe par nuit) et déviation standard (SD) de Pacifastacus leniusculus (PI) et Procambarus clarkii $(\mathrm{Pc})$ et résultats du test de Kruskal- Wallis et du test post hoc de Dwass-Steel-Critchlow-Fligner pour les comparaisons des CPUE de chaque espèce entre secteurs de rivière. Tous les échantillons sont pris en compte. Niveau de signification : ${ }^{*}=p<0,05 ;{ }^{* *}=p<0,01$; $* * *=p<0,001 ;$ ns $=$ non significatif.

\begin{tabular}{|c|c|c|c|c|c|c|}
\hline & \multirow[t]{2}{*}{ Mean CPUE (SD) } & \multicolumn{2}{|c|}{ Uppper sector } & \multicolumn{2}{|c|}{ Site 7} \\
\hline & & & PI & $\mathrm{PC}$ & PI & $\mathrm{PC}$ \\
\hline \multirow{2}{*}{$\begin{array}{l}\text { Upper sectors } \\
\text { (sites } 4,5,6 \text { ) }\end{array}$} & $\mathrm{PI}$ & $8.45(7.44)$ & & & & \\
\hline & $\mathrm{PC}$ & $0.25(0.10)$ & & & & \\
\hline \multirow[b]{2}{*}{ Site 7} & $\mathrm{PI}$ & $19.62(16.79)$ & ns & & & \\
\hline & $\mathrm{PC}$ & $1.36(1.80)$ & & ᄎ & & \\
\hline \multirow{2}{*}{$\begin{array}{l}\text { Lower sector } \\
\text { (sites } 8,9,10)\end{array}$} & $\mathrm{PI}$ & $6.00(6.80)$ & ns & & * & \\
\hline & $P C$ & $3.78(5.25)$ & & & & ns \\
\hline
\end{tabular}

November 2002 to April 2003, including an exceptional flood in December 2002 (Ponte Pinelo 04R/01H, SNIRH, www.snirh.pt) which may have washed downstream some specimens.

According to a previous study (Bubb et al., 2002), high flows appear to have no effect on downstream displacement of adult crayfish, contrary to expectations. The actual effect of high flows may depend on the current velocity and on the presence of larger substrate fractions which provide shelter for crayfish, decreasing the probability of being washed downstream. But small crayfish may be more easily transported downstream over long distances thus promoting downstream colonisation. Previous studies reported that high discharges caused downstream displacement of crayfish (Momot, 1966) and signal crayfish are known to be washed downstream by spates (Reeve, 2004), thus promoting a faster spread of the population. Several studies reported crayfish were more likely to move downstream or to spread downstream at higher rates (Reeve, 1990; Peay and Rogers, 1999; Light, 2003; Bubb et al., 2005) which seems to be confirmed by the results of this study. 
Differences in spread rates in a river system may be related to the particular conditions of each lotic sector which may be expressed by slope. Steeper slopes usually mean slower upstream movements, because of faster water flow and morphological conditions causing more difficult progression; on the contrary, the downstream movements tend to be more rapid. The spread rates observed in river sectors with different slopes (Figure 2) seems to suggest river conditions may explain to some extent differences in expansion rates.

Limiting resources, social pressure in high densities and predation pressure may be important drivers of expansion processes in animal populations. In the river Maçãs, substrate provides suitable cover and food resources are abundant (benthic invertebrates, detritus, aquatic vegetation). Apparently, these resources are not limiting factors in any reach of this river, with the possible exception of some high density situations which also reflect on increased social pressure. But predation pressure may be a relevant factor since otter is common in river Maçãs and exerts a strong predation pressure (crayfish is the main food item in local otter's diet, unpublished data). Expansion could be a consequence of crayfish up or downstream movements to avoid predators.

Crayfish progression faced no special difficulties - no large barriers exist, only a few small weirs, no high waterfalls and in all reaches the slope of the watercourse is relatively low (Table I). The main obstacle is the energy of the river during high flow events which may occur from late autumn to early spring. However, during late spring and summer, when crayfish are more active, the flow is low and river conditions are ideal for progression. Crayfish have high potential for self dispersal, including moving against water flow but also have well known abilities to move around obstacles, passing dams and waterfalls by walking on dry land (Hiley, 2003). With this behaviour they expose themselves to an increased predation, but increase their possibilities to find new habitats with higher resource availability with less competition and lower predation pressure.

The dispersal rates recorded in River Maçãs are similar or higher than reported in most studies. In Finland and England, reported rates range from 0.4 to a maximum of about $2 \mathrm{~km} \cdot \mathrm{yr}^{-1}$ and are frequently around $1 \mathrm{~km} \cdot \mathrm{yr}^{-1}$ (Westman and Nylund, 1979, Holdich et al., 1995; Peay, 1997; Guan and Wiles, 1997,1999; Peay and Rogers, 1999; Stanton, 2004; Bubb et al., 2005). Higher downstream expansion rates were reported for Austria, up to $7 \mathrm{~km} \cdot \mathrm{yr}^{-1}$ (Weinländer and Füreder, 2009) and for Croatia, 18-24.4 km. $\mathrm{yr}^{-1}$ (Hudina et al., 2009) though in this last case floods, the previously undetected presence of crayfish and human interference (translocating animals) cannot be excluded as a possible explanation for the exceptionally fast spread (Hudina et al., 2009).

The faster expansion recorded in this study compared with others might be related to the hydrological conditions from late spring to early autumn which are highly suitable for crayfish progression. A relatively long period of favourable water temperatures (150 days.year ${ }^{-1}$ above $14{ }^{\circ} \mathrm{C}$ ), longer than in most other European countries, may be also relevant as locomotion activity is temperature-related.

Information on $P$. clarkii upstream spreading is limited to a $8.7 \mathrm{~km}$ river sector, from site 6 to site 4 . After reaching site 4 , where CPUE remained low and fairly constant, red swamp crayfish did not continue the upstream expansion in the subsequent years. Though this is the upstream limit, which usually means that the species is facing some degree of environmental constraints, the upstream spread rate was as high as $1.74 \mathrm{~km} \cdot \mathrm{yr}^{-1}$.

Few studies reported the co-existence or the possibility of coexistence of $P$. leniusculus and $P$. clarkii. In Hokkaido, North Japan, coexistence was detected in a river receiving water from a hotspring (maximum temperature ca. $25^{\circ} \mathrm{C}$ ) (Nakata et al., 2005). In Europe, the coexistence was observed in England (CABI et al., 2005), in Spain (Alonso et al., 2001) and the reported distribution of both species in the west of France suggests the probable coexistence in some river stretches (Bramard et al., 2006). Coexistence was also reported for a small lake (maximum summer temperature $25^{\circ} \mathrm{C}$, minimum fall temperature $10^{\circ} \mathrm{C}$ ) in the state of Washington, NW USA, where the invader red swamp crayfish was found to be the dominant species outnumbering the native signal crayfish by more than two to one, probably meaning $P$. clarkii is displacing P. leniusculus inside of its natural range (Mueller, 2007a). 
In this study, crayfish were sampled with traps and in quantitative studies this option may raise a number of issues. In spite of trapping selectivity problems related to size, sex and reproductive stage (e.g. Policar and Kozák, 2005; Gallagher et al., 2006), traps are still the most frequently employed method of capturing crayfish Momot and Gowing, 1972; Byrne et al., 1999; Demers and Reynolds, 2002; Flotemersch and Jackson, 2003; Lyons and Kelly-Quinn, 2003; Martínez et al., 2003; Yamamoto, 2010). Previous studies have shown variable levels of aggression among different crayfish species (Figler et al., 1995, 1999; Gherardi et al., 1999; Gherardi and Daniels, 2004; Tierney et al., 2000; Alonso and Martínez, 2006; Luan, 2009) and in situations of coexistence, traps may underestimate the abundance of the less aggressive species. Electrofishing is possibly a more effective technique to detect and sample crayfish (e.g. Rabeni, 1997; Price and Welch, 2009; Gladman et al., 2010) butpresents major disadvantages, such as high cheliped loss (JMB pers. obs.; Alonso, 2001; Gladman et al., 2010) or the bias in quantitative studies resulting from inaccurate quantification of the capture effort. Moreover, in conditions of low water depth and cobble-boulder substrate, as in the Maçãs, electrofishing efficiency is severely affected. For all these reasons, in this study baited traps were considered as the best option. Even if the sampling selectivity may have caused some bias on the quantitative assessments of both species, the sampling method seems accurate enough to put in evidence the contrasting species proportions and abundances existing in the river Maçãs.

Our results show $P$. clarkii is significantly less abundant in the upper sites $(4,5,6)$ than in the intermediate (site 7$)$ and lower sites $(8,9,10)$. The signal crayfish is the dominating species in the upper and in the intermediate sites. The species interactions are usually complex processes involving a wide range of variables. Result from competition depend on different competition abilities regarding limiting resources and/or environmental conditions species will respond to with a higher or lower level of ecological comfort. The physiological and behavioral performances will depend on those habitat conditions. Regarding resources, apparently food is not a limiting resource in the Maçãs, as referred earlier. Shelter is frequently an important resource which may be critical for crayfish survival, serving as a refuge against predators and some environmental extremes and providing a suitable reproductive habitat. In conditions of low shelter availability, the higher ability of one of the species to compete for shelters may be a decisive factor. However, in the case of the Maçãs, sheltering ability does not appear to confer an advantage to one of the species as the cobble-boulder substrate provides high shelter availability.

The expansion limits and the differential distribution could then be the consequence of some environmental constraints. $P$. clarkii is often considered a warm-water species and $P$. leniusculus a cool water species. Typically, $P$. clarkii would predominate in slow-flowing lowland rivers with fine substrate and $P$. leniusculus in gravel and high energy watercourses with lower temperatures Procambarus clarkii exhibits both temperature preference and avoidance reactions when exposed to a broad thermal gradient and the final preferendum is within the $23.4^{\circ} \mathrm{C}-26.7^{\circ} \mathrm{C}$ range (Espina et al., 1993; Ramírez et al., 1994). But red swamp crayfish is able to thrive also at cooler climates at higher latitudes and altitudes (Frutiger et al., 1999; Mueller, 2007b; Ellis and England, 2008). P. clarkii can survive, breed and grow in the climatic conditions of UK (Richter and Wiles, 2000), Germany (Dehus et al., 1999), Netherlands (Henttonen and Huner, 1999) or Switzerland (Stucki, 1997). P. clarkii is an eurythermic species which can cope with seasonally low temperatures, e.g. surviving under ice (Dehus et al., 1999). Nevertheless, temperature may constrain population growth and expansion in river Maçãs (in site 4 maximum CPUE is 0.27). Upstream site 4, distribution did not expand apparently because population pressure was low and the environment of the upper reaches was seasonally uncomfortable and avoided. The colder temperatures of the upper reaches of river Maçãs are more favorable to signal crayfish which dominates. For $P$. leniusculus juveniles the temperature optimal for maximum growth is $23^{\circ} \mathrm{C}$ (Firkins and Holdich, 1993). The scope for activity of Pacifastacus leniusculus was determined between 5 and $30{ }^{\circ} \mathrm{C}$ and lethal temperature is $31-33^{\circ} \mathrm{C}$ (Becker et al., 1975; Rutledge and Pritchard, 1981; Nakata et al., 2002). In River Maçãs, the temperature tolerance limits of both species are never exceeded 
but minimum temperatures and possibly other environmental dimensions related to the upriver conditions affect $P$. clarkii more than $P$. leniusculus and seem the most probable cause for the observed differences of CPUE and species proportions. Laboratory studies showed P. clarkii wins agonistic interactions (Figler et al., 1995, 1999; Gherardi et al., 1999; Gherardi and Daniels, 2004; Alonso and Martínez, 2006) which strongly support the hypothesis that $P$. leniusculus dominance in most river sectors and the upper limit of $P$. clarkii distribution is mostly the result of environmental conditions.

The persistence of the crayfish coexistence remains to be seen and as both species are generalists and potential invaders, coexistence is expected to persist where both species face some degree of environmental stress, i.e., no dominance and displacement will happen because neither of them lives under optimal conditions.

\section{ACKNOWLEDGEMENTS}

The authors wish to thank Catherine Souty-Grosset for the French translation and two anonymous reviewers for their helpful comments and suggestions that greatly improved the manuscript.

\section{REFERENCES}

Alonso F., 2001. Efficiency of electrofishing as a sampling method for freshwater crayfish populations in small creeks. Limnetica, 20, 59-72.

Alonso F. and Martínez R., 2006. Shelter competition between two invasive crayfish species: a laboratory study. Bull. Fr. Pêche Piscic., 380-381, 1121-1132.

Alonso F., Temiño C. and Diéguez-Uribeondo J., 2001. Status of the white-clawed crayfish, Austropotamobius pallipes (Lereboullet, 1858), in Spain: distribution and legislation. Bull. Fr. Pêche Piscic., 356, 31-54.

Becker C.D., Genoway R.G. and Merrill J.A., 1975. Resistance of northwestern crayfish, Pacifastacus leniusculus (Dana) to elevated temperatures. Trans. Am. Fish. Soc., 104, 374-387.

Bernardo J.M. and Ilhéu M., 1994. Red swamp crayfish (Procambarus clarkii): contribution to material cycling. Verh. Internat. Verein Limnol., 25, 2447-2449.

Bernardo J.M., Bruxelas S., Bochechas J. and Costa A.M., 2001. Freshwater crayfish in Portugal: a new Astacidae, Pacifastacus leniusculus (Dana), and less perspectives for the rehabilitation of the native Austropotamobius pallipes, Actas do $2^{\circ}$ Congresso Nacional de Conservação da Natureza, CD edition, Instituto de Conservação da Natureza, Lisboa, 1-6.

Bramard M., Demers A., Trouilhe M.-C., Bachelier E., Dumas J.-C., Fournier C., Broussard E., Robin O., Souty-Grosset C. and Grandjean F., 2006. Distribution of the indigenous and non-indigenous crayfish populations in the Poitou-Charentes region (France): Evolution of the past 25 years. Bull. Fr. Pêche Piscic., 380-381, 857-866.

Bubb D.H., Lucas M.C. and Thom T.J., 2002. Winter movements and activity of signal crayfish Pacifastacus leniusculus in an upland river, determined by radio telemetry. Hydrobiologia, 483, 111-119.

Bubb D.H., Thom T.J. and Lucas M.C., 2005. The within catchment invasion of the non-indigenous signal crayfish Pacifastacus leniusculus (Dana), in upland rivers. Bull. Fr. Pêche Piscic., 376-377, 665-673.

Byrne C.F., Lynch J.M. and Bracken J.J., 1999. A sampling strategy for stream populations of white clawed crayfish Austropotamobius pallipes (Lereboullet) (Crustacea, Astacidae). Biology and Environment, 99B, 89-94.

CABI, CEFAS, CEH, CSL, IC and UoG, 2005. UK Non-Native Organism Risk Assessment Scheme. Version 3.3. Prepared by $\mathrm{CABI}$ Bioscience (CABI), Centre for Environment, Fisheries and Aquaculture Science (CEFAS), Centre for Ecology and Hydrology (CEH), Central Science Laboratory (CSL), Imperial College London (IC) and the University of Greenwich (UoG) under Defra Contract CR0293, https://secure.fera.defra.gov.uk/nonnativespecies/ (accessed 10 September 2010). 
DAISIE - European Invasive Alien Species Gateway, 2010. One hundred of the worst, http://www. europe-aliens.org/speciesTheWorst.do (accessed 30 July 2010).

Dehus P., Bohl E., Oidtmann B., Keller M. and Lechleiter S., 1999. German conservation strategies of native crayfish species with regard to alien crayfish. In: Gherardi F. and Holdich D.M. (eds.), Crustacean Issues, 11, Crayfish in Europe as Alien Species, A.A. Balkema, Rotterdam, 149-159.

Demers A. and Reynolds J.D., 2002. A survey of the white-clawed crayfish, Austropotamobius pallipes (Lereboullet), and of water quality in two catchments of Eastern Ireland. Bull. Fr. Pêche Piscic., $367,729-740$.

Diéguez-Uribeondo J., 2006. The dispersion of the Aphanomyces astaci carrier Pacifastacus leniusculus by humans represents the main cause of disappearance of the indigenous crayfish Austropotamobius pallipes in Navarra. Bull. Fr. Pêche Piscic., 380-381, 1303-1312.

Ellis A. and England J., 2008. Red swamp crayfish on the move in the UK. Crayfish News: IAA Newsletter, $30,4$.

Espina S., Herrera F.D. and Buckle L.F., 1993. Preferred and avoided temperatures in the crawfish, Procambarus clarkii. J. Therm. Biol., 18, 35-39.

Figler M.H., Twum M., Finkelstein J.E. and Peeke H.V.S., 1995. Maternal aggression in red swamp crayfish (Procambarus clarkii, Girard): the relation between reproductive status and outcome of aggressive encounters with male and female conspecifics. Behaviour, 132, 10-121.

Figler M.H., Cheverton H.M., and Blank G.S., 1999. Shelter competition in juvenile red swamp crayfish (Procambarus clarkii): the influences of sex differences, relative size, and prior residence. Aquaculture, 178, 63-75.

Firkins I. and Holdich D.M., 1993. Thermal studies with three species of freshwater crayfish. Freshwater Crayfish, 9, 241-248.

Flotemersch J.E. and Jackson D.C., 2003. Seasonal foraging by channel catfish on terrestrial burrowing crayfish in a floodplain-river ecosystem. Ecohydrology and Hydrobiology, 3, 61-70.

Frutiger A., Borner S., Büsser T., Eggen R., Müller R., Müller S. and Wasmer H.R., 1999. How to control unwanted populations of Procambarus clarkii in Central Europe? Freshwater Crayfish, 12, 714-726.

Gallagher M.B., Dick J.T.A. and Elwood R.W., 2006. Riverine habitat requirements of the white-clawed crayfish, Austropotamobius pallipes. Biology and Environment: Proceedings of the Royal Irish Academy, 106B, 1-8.

Gherardi F. and Daniels W.H., 2004. Agonism and shelter competition between invasive and indigenous crayfish species. Can. J. Zool., 82, 1923-1932.

Gherardi F., Barbaresi S. and Raddi A., 1999. The agonistic behaviour of red swamp crayfish Procambarus clarkii: functions of the chelae. Freshwater Crayfish, 12, 233-243.

Gladman Z.F., Yeomans W.E., Adams C.E., Bean C.W., McColl D., Olszewska J.P., McGillivray C.W. and McCluskey R., 2010. Detecting North American signal crayfish (Pacifastacus leniusculus) in riffles. Aquat. Conserv., 20, 588-594.

Guan R.-Z. and Wiles P.R., 1997. The home range of signal crayfish in a British lowland river. Freshwater Forum, 8, 45-54.

Guan R. and Wiles P.R., 1999. Growth and reproduction of the introduced crayfish Pacifastacus leniusculus in a British lowland river. Fishery Research, 42, 245-259.

Gutiérrez-Yurrita P.J., Martinez J.M., Ilhéu M., Bravo-Utrera M.A., Bernardo J.M. and Montes C., 1999. The status of crayfish populations in Spain and Portugal. In: Gherardi F. and Holdich D.M. (eds.), Crayfish in Europe as Alien Species. How to make the best of a bad situation?, A.A. Balkema, Rotterdam, 161-192.

Henttonen P. and Huner J.V., 1999. The introduction of alien species of crayfish in Europe, a historical introduction. In: Gherardi F. and Holdich D.M. (eds.), Crayfish in Europe as Alien Species. How to make the best of a bad situation?, A.A. Balkema, Rotterdam, 13-22.

Hiley P.D., 2003. The slow quiet invasion of signal crayfish (Pacifastacus leniusculus) in England prospects for the white-clawed crayfish (Austropotamobius pallipes). In: Holdich D.M. and Sibley P.J. (eds.), Management and Conservation of Crayfish, Proceedings of a conference held in Nottingham on 7 November 2002, Environment Agency, Bristol, 127-138.

Hobbs W.B., Jass J.P. and Huner J.V., 1989. A review of global crayfish introductions with particular emphasis on two North American species (Decapoda, Cambaridae). Crustaceana, 56, 299-316. 
Holdich D.M., 2002. Biology of Freshwater Crayfish, Blackwell, Oxford, 702 p.

Holdich D.M., Rogers W.D. and Reader J.P., 1995. Crayfish Conservation, Final Project Record, R \& D 378 National Rivers Authority, Bristol.

Holdich D.M., Rogers W.D. and Reynolds J.D., 1999. Native and alien crayfish in the British Isles. In: Gherardi F. and Holdich D.M. (eds.), Crayfish in Europe as Alien Species. How to make the best of a bad situation?, A.A. Balkema, Rotterdam, 221-236.

Hudina S., Faller M., Lucić A., Klobučar G. and Maguire I., 2009. Distribution and dispersal of two invasive crayfish species in the Drava River basin, Croatia. Knowl. Managt. Aquatic Ecosyst., 394-395, 09.

Jeschke J.M. and Strayer D.L., 2006. Determinants of vertebrate invasion success in Europe and North America. Glob. Chan. Biol., 12, 1608-1619.

Light T., 2003. Success and failure in a lotic crayfish invasion: the roles of hydrologic variability and habitat alteration. Freshw. Biol., 48, 1886-1897.

Lodge D.M., Taylor C.A., Holdich D.M. and Skurdal J., 2000a. Nonindigenous crayfishes threaten American freshwater biodiversity. Fisheries, 25, 7-20.

Lodge D.M., Taylor C.A., Holdich D.M. and Skurdal J., 2000b. Reducing impacts of exotic crayfish introductions, new policies needed. Fisheries, 25, 21-23.

Luan X., 2009. Interspecies aggression and social dominance in crayfish, Ph.D. thesis, Graduate College of Bowling Green State University, Bowling Green.

Lyons R. and Kelly-Quinn M., 2003. An investigation into the disappearance of Austropotamobius pallipes (Lereboullet) populations in the headwaters of the Nore River, Ireland and the correlation to water quality. Bull. Fr. Pêche Piscic., 370-371, 139-150.

Martínez R., Rico E. and Alonso F., 2003. Characterisation of Austropotamobius italicus (Faxon, 1914) populations in a Central Spain area. Bull. Fr. Pêche Piscic., 370-371, 43-56.

Millenium Ecosystem Assessment, 2005. Ecosystems and human well-being: Biodiversity synthesis, World Resources Institute, Washington, D.C.

Momot W.T., 1966. Upstream movement of crayfish in an intermittent Oklahoma stream. Am. Midl. Nat., $75,150-159$.

Momot W.T., 1995. Redefining the role of crayfish in aquatic ecosystems. Reviews Fish. Sci., 3, 33-63.

Momot W.T. and Gowing H., 1972. Differential seasonal migration of the crayfish Orconectes virilis (Hagen) in marl lakes. Ecology, 53, 479-483.

Mueller K.W., 2007a. Status of the crayfish stocks in Pine lake, King County, Washington five years after the discovery of the invasive red swamp crayfish Procambarus clarkii (Girard, 1852). J. Freshwater Ecol., 22, 351-353.

Mueller K.W., 2007b. Reproductive habits of non-native red swamp Crayfish (Procambarus clarkii) at Pine lake, Sammamish, Washington. Northwest Science, 81, 246-250.

Nakata K., Hamano T., Hayashi K.-I. and Kawai T., 2002. Lethal limits of high temperature for two crayfishes, the native species Cambaroides japonicus and the alien species Pacifastacus leniusculus in Japan. Fish. Sci., 68, 763-767.

Nakata K., Tsutsumi K., Kawai T. and Goshima S., 2005. Coexistence of two North American invasive crayfish species, Pacifastacus leniusculus (Dana, 1852) and Procambarus clarkii (Girard, 1852) in Japan. Crustaceana, 78, 1389-1394.

Ninyerola M., Pons X. and Roure J.M., 2005. Atlas Climático Digital de la Península lbérica. Metodología y aplicaciones en bioclimatología y geobotánica Universidad Autónoma de Barcelona, Bellaterra, http://www.opengis.uab.es/wms/iberia/ (accessed 1 October 2010).

Nyström P., 2002. Ecology. In: Holdich D.M. (ed.), Biology of Freshwater Crayfish, Blackwell Scientific Press, Oxford, 192-224.

Peay S., 1997. Night survey for crayfish in the River Wharfe, Yorkshire, Master's thesis, University of Hull, $120 \mathrm{p}$.

Peay S. and Rogers D., 1999. The peristaltic spread of signal crayfish (Pacifastacus leniusculus) in the River Wharfe, Yorkshire, England. Freshwater Crayfish, 12, 665-676.

Policar T. and Kozák P., 2005. Comparison of trap and baited stick catch efficiency for noble crayfish (Astacus astacus L.) in the course of the growing season. Bull. Fr. Pêche Piscic., 376-377, 675-686. 
Price J.E. and Welch S.M., 2009. Semi-quantitative methods for crayfish sampling: sex, size, and habitat bias. J. Crustac. Biol., 29, 208-216.

Rabeni C.F., 1997. Evaluating techniques for sampling stream crayfish (Paranephrops planifrons). N. Z. J. Mar. Freshwater Res., 31, 693-700.

Ramírez L.F.B., Herrera F.D., Sandoval F.C., Sevilla B.B. and Rodriguez M.H., 1994. Diel thermoregulation of the crawfish Procambarus clarkii (Crustacea, Cambaridae). J. Thermal Biol., 19, 419-422.

Reeve I.D., 1990. Aspects of the biology of an introduced and a native species of freshwater crayfish, Ph.D. thesis, University of Nottingham, UK.

Reeve I.D., 2004. The removal of the North American signal crayfish (Pacifastacus leniusculus) from the River Clyde, Scottish Natural Heritage Commissioned Report No. 020 (ROAME No. F00LI12).

Richter K. and Wiles R., 2000. Red swamp crayfish breeding in Britain. Crayfish News, 23, 3.

Rutledge P.S. and Pritchard A.W., 1981. Scope for activity in the crayfish Pacifastacus leniusculus. Am. J. Physiol. Regul. Integr. Comp. Physiol, 240, 87-92.

Souty-Grosset C., Holdich D.M., Noël P.Y., Reynolds J.D. and Haffner P. (eds.), 2006. Atlas of Crayfish in Europe, Muséum national d'Histoire naturelle, Patrimoines naturels, 64, Paris, $187 \mathrm{p}$.

Stanton J., 2004. Burrowing Behavior and Movements of the Signal Crayfish, Unpublished Ph.D. Thesis, University of Leicester, UK.

Stucki T.P., 1997. Three American crayfish species in Switzerland. In: Momot W.T. (ed.), Freshwater Crayfish, 11, LSU Graphic Service, Louisiana State University, Baton Rouge, 130-133.

Taylor C.A., 2002. Taxonomy and conservation of native crayfish stocks. In: Holdich D.M. (ed.), Biology of Freshwater Crayfish, Blackwell Scientific, Oxford, 236-256.

Tierney A.J., Godleski M.S. and Massanari J.R., 2000. Comparative analysis of agonistic behavior in four crayfish species. J. Crustac. Biol., 20, 54-66.

Weinländer M. and Füreder L., 2009. The continuing spread of Pacifastacus leniusculus in Carinthia (Austria). Knowl. Managt. Aquatic Ecosyst., 394-395, 17.

Westman K. and Nylund V., 1979. Crayfish plague, Aphanomyces astaci, observed in the European crayfish, Astacus astacus in Pihlajavesi waterway in Finland. A case study on the spread of the plague fungus. Freshwater Crayfish, 4, 419-426.

Yamamoto Y., 2010. Contribution of bioturbation by the red swamp crayfish Procambarus clarkii to the recruitment of bloom-forming cyanobacteria from sediment. J. Limnol., 69, 102-111. 